\title{
THINK-GROUP-SHARE MENINGKATKAN KEMAHIRAN BERKONGSI DALAM KALANGAN MURID PRASEKOLAH
}

Think-Group-Share Improve Sharing Skills Amongst Preschool Students

Wan Kit Yee ${ }^{1}$, Sharifah Hanim Binti Syed Akbar ${ }^{2}$

IPG Kampus Bahasa Melayu, Lembah Pantai, Kuala Lumpur

kityee_93@ hotmail.com ${ }^{1}$, sharifahhanim@yahoo.com ${ }^{2}$

\begin{abstract}
ABSTRAK
Kemahiran berkongsi merupakan aspek penting dalam perkembangan sosioemosi kanak-kanak. Kaedah yang sesuai dengan keperluan murid prasekolah akan memudahkan proses pembelajaran. Oleh itu, kajian tindakan ini bertujuan untuk menilai keberkesanan kaedah Think-Group-Share dalam meningkatkan kemahiran berkongsi yang terkandung dalam perkembangan sosioemosi kanak-kanak. Terdapat empat peserta kajian yang berumur enam tahun dalam kajian ini. Think-Group-Share adalah kaedah yang telah diubahsuai oleh pengkaji berdasarkan model pembelajaran koperatif oleh Spencer Kagan (Cooperative Learning). Kaedah ini menekankan proses berfikir (Think), berkumpulan (Group) dan berkongsi (Share). Kemahiran yang diberi perhatian merangkumi berkongsi dan nilai-nilai murni. Intervensi berlangsung selama empat minggu, iaitu lima hari seminggu. Data dikumpul melalui pemerhatian, temu bual dan analisis dokumen. Dapatan analisis ujian menunjukkan peningkatan mendadak melebihi sebanyak 50 kali untuk empat peserta kajian. Hasil dapatan menunjukkan kaedah ini membolehkan peserta kajian menguasai kemahiran berkongsi dan nilai-nilai semasa menjalankan aktiviti. Dengan ini, peserta kajian dapat berkongsi dan memupuk nilai murni dalam aktiviti yang dirancangkan. Memandangkan keberkesanan kaedah ini, kajian lanjut boleh
\end{abstract}


Think-Group-Share Meningkatkan Kemahiran Berkongsi

Dalam Kalangan Murid Prasekolah

memfokuskan setiap tunjang dengan lebih spesifik serta melihat kesan dalam proses pengajaran dan pembelajaran.

Kata Kunci: prasekolah, berkongsi, Think-Group-Share, sosioemosi, cooperative learning

\begin{abstract}
Sharing is an important aspect in social emotional development. The effective method will facilitate and enhance learning process. Therefore, this action research aims to evaluate the effectiveness of Think-Group-Share to help respondents to improve sharing skill in the domain of social emotional. Respondents in this study consisted of four of six years old preschool students. Think-Group-Share was adapted from Kagan's Model of Cooperative Learning which designed by Spencer Kagan. This method focuses the processes of "Think", "Group" and "Share". Focused skills for intervention include sharing and moral values. The intervention lasted for four weeks and five days a week. Data were collected through observation, interview and documents analysis. The analysis of findings showed a sharp increase which was at least 50 times of improvement for four respondents. The findings showed that Think-Group-Share can improved sharing skill and moral values with the use of effective intervention strategies. Thus, respondents can share and instill moral values in activities planned. As this effectiveness of method, further study can concentrate every domain of early childhood education with specifically examine the effectiveness Think-Group-Share in teaching and learning process.
\end{abstract}

Keywords: preschool, sharing, Think-Group-Share, socioemotional, cooperative learning 
Jurnal Pendidikan Awal Kanak-Kanak Kebangsaan 2017 Special Issue (48-66)

(ISSN 2289-3032 / eISSN 2550-178X)

https://ejournal.upsi.edu.my/journal/JPAK

\section{PENGENALAN}

Murid prasekolah merupakan modal insan kepada negara. Oleh itu, mereka perlu diberi perhatian supaya dapat berkembang secara menyeluruh iaitu dari aspek jasmani, emosi, rohani, intelek dan sosial (JERIS). Dalam hal ini, belajar melalui bermain merupakan satu pendekatan yang amat penting dalam perkembangan murid prasekolah. Pendekatan belajar melalui bermain bukan sahaja dapat memberi keseronokan semasa pembelajaran tetapi juga membantu perkembangan JERIS. Froebel juga mengatakan bahawa kanak-kanak perlu dilibatkan dalam permainan yang bermakna agar membantu perkembangan dan pendidikan pada masa depan. (Provenzo, 2009). Pendekatan yang seronok dan bermakna ini terus akan membantu murid prasekolah mencapai tahap yang optimum dalam setiap perkembangan. Merujuk Kurikulum Standard Prasekolah Kebangsaan (2010), pendidikan prasekolah berfokus kepada usaha untuk menyediakan peluang pembelajaran yang menyeronokkan dan bermakna kepada kanak-kanak berumur empat hingga enam tahun (Dokumen KSPK). Dalam erti kata lain, guru memainkan peranan yang penting dalam merancang dan menyediakan aktiviti yang sesuai dalam proses pengajaran dan pembelajaran kerana bermain dapat melibatkan kolaborasi antara satu sama lain. Berdasarkan Boyd et al. (2005) dalam NIEER, perkembangan sosial dan emosional sebagai satu pemudah cara dalam perkembangan kognitif. Oleh itu, perkembangan sosioemosi kanak-kanak harus diberi perhatian supaya kanak-kanak dapat berkembang dengan menyeluruh dari segi jasmani, emosi, rohani, intelek dan rohani seperti dihasratkan dalam Falsafah Pendidikan Kebangsaan.

Menurut Pellegrini (2009), semasa bermain sosial, kanak-kanak dapat berkomunikasi dengan efektif antara satu sama lain sama ada secara lisan dan bukan lisan. Untuk memulakan interaksi koperatif, rangsangan perlu disediakan dan menetapkan tujuan interaksi. Berdasarkan Short-Meyerson 
(2010), main koperatif membolehkan kanak-kanak untuk mencari pengetahuan bersama untuk mewujudkan matlamat yang sama melalui interaksi dalam permainan. Ini boleh menggalakkan penglibatan kanak-kanak dalam mencari penyelesaian masalah dengan lebih berkesan. Oleh itu, penggunaan tema dicadang diaplikasikan dalam pembelajaran supaya boleh menyokong dan meningkatkan proses penyelesaian masalah kanak-kanak. Contohnya, perancangan, proses kerjasama, penglibatan, perbincangan, dan perundingan (Ramani, 2013). Tambahan pula, para pengkaji pendidik awal kanak-kanak juga kerap menggunakan permainan dalam bilik darjah untuk memotivasikan pembelajaran kanak-kanak dan memupuk minat dalam aspek matematik, celik huruf, dan penyelesaian masalah (Hirsh-Pasek et al., 2009).

Berdasarkan Cambridge Dictionaries Online, "sharing" bermaksud "to have or use something at the same time as someone else", "If two or more people share an activity, they each do some of it" and "If two or more people or things share a feeling, quality, or experience, they both or all have the same feeling, quality, or experience". Manakala Oxford Dictionaries (2016) mentakrifkan "share" sebagai "a part or portion of a larger amount which is divided among a number of people, or to which a number of people contribute", "a person's part in or contribution to something" dan "have a portion of (something) with another or others". Dalam hal ini, didapati bahawa murid prasekolah sukar untuk berkongsi. Berdasarkan pengalaman mengajar kali keempat, iaitu semasa pengkaji menjalankan praktikum fasa III di sebuah prasekolah di daerah Kuala Lumpur. Pengkaji mendapati bahawa ramai murid prasekolah mengalami masalah berkongsi bahan semasa aktiviti kumpulan. Mereka sering berebut bahan semasa aktiviti berkumpulan dijalankan sehingga proses pengajaran dan pembelajaran terganggu. Semasa proses pengajaran dan pembelajaran terutamanya dalam aktiviti kumpulan yang berpusatkan murid, murid juga sering mengadu dengan guru yang sedang mengajar. Contohnya, "cikgu, murid X ambil barang saya", "cikgu, murid X tak nak kongsi dengan saya dan "cikgu, murid X berebut". Selain 
Jurnal Pendidikan Awal Kanak-Kanak Kebangsaan 2017 Special Issue (48-66)

(ISSN 2289-3032 / eISSN 2550-178X)

https://ejournal.upsi.edu.my/journal/JPAK

itu, situasi seperti berebut, jerit-menjerit dan bergaduh juga menunjukkan kelemahan murid semasa mengadakan aktiviti kumpulan. Berdasarkan pandangan dari Wexner Medical Center (2012), "Sharing among children can sometimes be an adventure". Ini menerangkan bahawa kanak-kanak adalah sukar untuk berkongsi dan kemahiran berkongsi ini adalah susah dicapai tahapnya.

Selain itu, Brogle, Jiron dan Giacomini (2013) mengatakan bahawa kemahiran berkongsi bukan dilahirkan secara semula jadi tetapi ia merupakan suatu kemahiran yang perlu diajar. Oleh itu, pengkaji mengambil inisiatif untuk mengadakan langkah-langkah yang boleh membantu meningkatkan kemahiran berkongsi dalam kalangan murid prasekolah. Sepanjang proses kajian tindakan ini, pengkaji akan menggunakan kaedah triangulasi dalam pengumpulan data dan analisis data. Pengkaji akan mengumpul data melalui pemerhatian, temu bual dan analisis dokumen. Segala data yang dikumpul akan dianalisis. Untuk mengekalkan kebolehpercayaan dan kesahan, rakaman video, pengesahan oleh pemerhati kedua dan rujukan pakar akan menjadi salah satu triangulasi bukti yang kukuh. Ini adalah selari dengan pandangan Bagnato (2007) yang mengatakan bahawa pentaksiran haruslah bersifat autentik. Penilaian autentik merupakan satu sistem pemerhatian, dokumentasi, dan proses menganalisis yang akan membantu perkembangan kanak-kanak memenuhi dan mencapai standard.

\section{Fokus Kajian}

Fokus kajian tidak menghadapi masalah dari segi kebolehtadbiran kerana pengkaji merupakan guru prasekolah semasa tempoh praktikum selama tiga bulan. Justeru, pengkaji mempunyai masa yang mencukupi untuk mendapatkan data untuk dianalisis, mengenal pasti punca tingkah laku murid, pemilihan kumpulan sasaran, pelaksanaan pemerhatian. Bukan itu sahaja, intervensi kaedah Think-Group-Share juga dapat dilaksanakan semasa pengkaji menjalankan proses pengajaran dan pembelajaran di dalam kelas 
mahupun di luar kelas kerana fokus kajian yang dipilih adalah tingkah laku murid yang perlu diberi perhatian sepanjang masa. Tambahan pula, kaedah pelaksanaan intervensi yang digunakan adalah bersistematik untuk dijalankan.

Rasionalnya kajian ini dijalankan untuk memperkukuhkan kemahiran berkongsi bahan antara murid. Menurut raisingchildren.net.au, kemahiran berkongsi merupakan satu kemahiran yang penting dalam kehidupan. Kemahiran berkongsi ini perlu dididik supaya kanak-kanak berpeluang untuk berkawan dan bermain bersama (Raising Children Network, 2006 - 2016). Main koperatif juga membantu kanak-kanak menunjukkan sikap berkongsi, sayang menyayangi dan penghargaan kepada rakan (Lyons, 2016). Secara praktiknya, kemahiran berkongsi mempunyai nilai yang tinggi dan kemahiran ini penting dalam membantu perkembangan seseorang kanak-kanak pada masa akan datang.

Kaedah intervensi yang ingin diaplikasikan dalam kajian ini merupakan kaedah praktikal. Intervensi yang dijalankan mempunyai kebolehgunaan yang memerlukan pengalaman konkrit yang berstruktur. Ini juga bertepatan dengan tokoh Piaget yang pernah mengatakan murid prasekolah berada di peringkat praoperasi perlu belajar secara berperingkat. Oleh itu, kaedah yang diadaptasikan dalam intervensi merupakan fokus utama keberkesanan pelaksanaan kaedah intervensi yang telah dijalankan.

Dari aspek kawalan pelaksanaan kaedah intervensi, tidak mempunyai sebarang kekangan dan rintangan dari segi masa kerana pengkaji merupakan seorang guru prasekolah praktikal di sekolah tersebut. Pengkaji dapat menjalankan kaedah yang dirancang semasa proses pengajaran dan pembelajaran berlangsung. Selain itu, pengkaji juga tidak perlu mengganggu waktu rehat dan lepas sekolah dalam melaksanakan kaedah intervensi kerana intervensi yang dirancang dapat dijalankan semasa proses pdp. 
Jurnal Pendidikan Awal Kanak-Kanak Kebangsaan 2017 Special Issue (48-66)

(ISSN 2289-3032 / eISSN 2550-178X)

https://ejournal.upsi.edu.my/journal/JPAK

Suatu kajian yang berjaya dan sempurna memerlukan kolaborasi dengan pelbagai pihak untuk menjamin kualiti kajian yang dilakukan. Pengkaji telah mengambil kesempatan untuk mengadakan sesi temu bual bersama dengan guru prasekolah pendidikan khas yang berperanan sebagai pemerhati kedua dalam pelaksanaan kaedah intervensi. Bagi memastikan kesinambungan pelaksanaan kaedah intervensi juga, pengkaji turut mengambil inisiatif untuk berbincang dengan guru prasekolah agar mendapat maklumat seperti dokumen pentaksiran perkembangan murid. Segala pengumpulan maklumat, data dari pemerhatian, temu bual dan analisis dokumen dapat meningkatkan lagi nilai kebolehpercayaan dan kesahan.

Seterusnya, kerelevanan kajian adalah sejurus sahaja pelaksanaan kaedah intervensi ini dijalankan, pengkaji percaya ini mampu membantu meningkatkan ilmu pengetahuan dan pengalaman murid. Ini merupakan peluang yang terbaik dan landasan untuk murid meningkatkan prestasinya sama ada dalam bidang akademik mahupun non-akademik. Lagipun, intervensi yang dijalankan akan turut membantu meningkatkan motivasi kendiri murid secara tidak langsung.

\section{Isu Keprihatinan}

Pengalaman mengajar di Sekolah Kebangsaan dan Sekolah Jenis Kebangsaan membolehkan pengkaji mengkaji murid prasekolah yang berbeza dari segi latar belakang dan kaum. Walau bagaimanapun, pengkaji mendapati bahawa terdapat ciri-ciri masalah pembelajaran yang sama semasa pembelajaran berpusatkan murid. Masalah yang dapat dikenal pasti dalam kalangan murid iaitu masalah berkongsi bahan semasa aktiviti kumpulan dijalankan. Pengalaman praktikum fasa I dan II memberi kesedaran kepada pengkaji bahawa masalah-masalah yang dinyatakan di atas bukan sekadar berlaku pada murid sekolah jenis kebangsaan, tetapi juga berlaku pada murid di sekolah kebangsaan. 
Oleh sebab masalah tingkah laku berkongsi, fokus utama dalam kajian ini ialah (PSE 3.0) membina kemahiran sosial. Standard kandungan ialah (PSE 3.2) menggunakan kemahiran sosial dalam interaksi. Manakala standard pembelajaran yang dipilih ialah (PSE 3.2.7) berkongsi idea, barangan dan peralatan. Aspek penting dalam perkembangan sosioemosi ialah perkembangan sosial dan tingkah laku pro-sosial. Kemahiran berkongsi turut menjadi salah satu standard pembelajaran dalam tunjang perkembangan sosioemosi dalam Kurikulum Standard Prasekolah Kebangsaan berdasarkan Kementerian Pelajaran Malaysia (2010).

Ringkasnya, murid menghadapi masalah berkongsi bahan semasa proses pengajaran dan pembelajaran diadakan. Pada pendapat pengkaji, strategi pembelajaran yang sesuai dengan murid prasekolah adalah penting untuk program intervensi dalam menyelesaikan masalah tersebut. Dalam hal ini, kaedah intervensi "Think-Group-Share" sesuai untuk menangani masalah kemahiran berkongsi kanak-kanak. Kerja kumpulan merupakan waktu murid mengadakan sesuatu aktiviti dalam kumpulan. Dengan erti kata lain, pembelajaran koperatif adalah sesuai untuk membantu meningkatkan kemahiran berkongsi bahan dalam kalangan murid prasekolah kerana pembelajaran koperatif (Think-Group-Share) adalah satu sistem pembelajaran yang memberi kanak-kanak peluang bekerjasama dalam tugas-tugas yang berstruktur (Yunus Abidin, 2010).

\section{Objektif dan Soalan Kajian}

\section{Objektif Kajian}

1. Penggunaan Think-Group-Share membantu meningkatkan kemahiran berkongsi dalam kalangan murid prasekolah.

2. Penggunaan Think-Group-Share membantu memupuk nilai kerjasama dalam kalangan murid prasekolah. 
Jurnal Pendidikan Awal Kanak-Kanak Kebangsaan 2017 Special Issue (48-66)

(ISSN 2289-3032 / eISSN 2550-178X)

https://ejournal.upsi.edu.my/journal/JPAK

\section{Soalan Kajian}

1. Adakah penggunaan Think-Group-Share membantu meningkatkan kemahiran berkongsi dalam kalangan murid prasekolah?

2. Adakah penggunaan Think-Group-Share membantu memupuk nilai kerjasama dalam kalangan murid prasekolah?

\section{Peserta Kajian}

Pengkaji telah menyasarkan kajian tindakan ini kepada murid pendidikan prasekolah di sekitar kawasan Kuala Lumpur. Kajian ini hanya melibatkan empat orang peserta kajian sahaja. Pengkaji memilih 4 daripada 10 orang peserta kajian yang berumur 6 tahun kerana mereka perlu diberi keutamaan dan pengukuhan yang sepatutnya supaya tidak menghadapi masalah semasa menaik ke tahap 1 nanti. Selain itu, Keempat-empat peserta dipilih kerana didapati kekerapan tidak menunjukkan tingkah laku berkongsi dalam seminggu. Berikut merupakan latar belakang peserta kajian A, B, C dan D. Peserta kajian A merupakan anak ke-2 dalam keluarga. Pemerhatian pengkaji semasa pengajaran mendapati peserta kajian suka belajar melalui tayangan video dan lagu. Peserta kajian B berasal daripada sebuah keluarga yang kurang berada. Ibu bapa Peserta kajian B telah bercerai dan Peserta kajian B tinggal bersama ibunya. Ibu Peserta kajian B merupakan seorang peniaga dan selalu bekerja pada waktu malam. Peserta kajian $\mathrm{C}$ seorang yang manja dan suka merajuk di depan guru yang disukai olehnya. Pengkaji mendapati peserta kajian $\mathrm{C}$ bertingkah laku sedemikian adalah disebabkan ibu bapanya mendapat anak ini pada usia yang lanjut. Peserta kajian D merupakan anak pertama dalam keluarga. Peserta kajian D seorang kanak-kanak yang riang dan suka bermain. Peserta kajian D agak lemah dalam subjek Bahasa Malaysia berbanding dengan peserta kajian yang lain. 


\section{Metodologi Kajian}

\section{Pengumpulan Data}

Metodologi dalam kajian ini antaranya termasuk pemerhatian, analisis dokumen dan temu bual (Rajah 2). Pengkaji menggunakan pemerhatian, senarai semak dan temu bual untuk mengetahui tahap penguasaan kemahiran berkongsi peserta kajian sebelum intervensi dijalankan. Ketiga-tiga cara ini adalah saling berkait dan dapat menjadi bukti antara satu sama lain apabila data dianalisis. Ketiga-tiga ini juga membantu pengkaji mengenal pasti secara khusus kesulitan-kesulitan yang dihadapi oleh keempat-empat orang peserta kajian.

Semasa pemerhatian, senarai semak perkembangan sosioemosi digunakan untuk mencatat tingkah laku berkongsi. Item-item senarai semak adalah diadaptasi dan diubahsuai dari Teaching \& Learning Company, The McGraw-Hill Companies, First Look and The Early Childhood Direction Center dan Kurikulum Standard Prasekolah Kebangsaan (Lampiran B). Ketiga-tiga metodologi kajian ini adalah saling berkait antara satu sama lain untuk mendapatkan maklumat yang sahih. Selain itu, langkah-langkah tindakan (intervensi) yang utama iaitu melalui lisan, tindakan dan aktiviti juga dibincang dengan lebih teliti. Selain itu, maklumat yang diperoleh juga melalui analisis dokumen. Dokumen rekod anekdot yang dicatat oleh guru prasekolah ialah sumber utama instrumen pentaksiran perkembangan murid prasekolah. Akhirnya, pengkaji juga menjalankan temu bual dengan guru prasekolah pendidikan khas dalam kajian. Beliau juga sebagai pemerhati kedua kerana beliau berada dalam prasekolah kebanyakan masa untuk melaksanakan Program Pendidikan Khas Integrasi. 


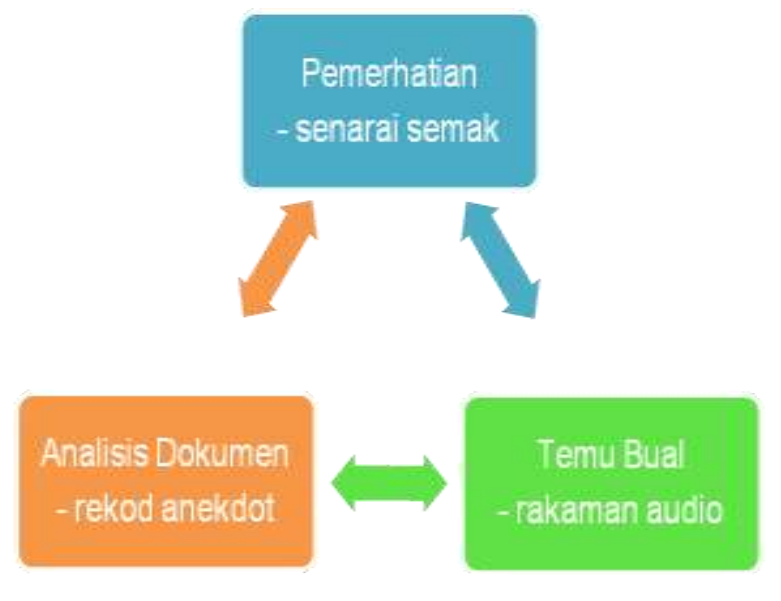

Rajah 1: Cara-cara pengumpulan data

Pengkaji telah mengambil keputusan untuk menjalankan kajian ini berasaskan Model Kagan. Think-Group Share yang merupakan pengubahsuaian Think-Pair-Share daripada Model Kagan. Terdapat 3 proses utama dalam kaedah Think-Group-Share. Proses pertama (Think), murid diberi masa yang cukup untuk memikirkan intervensi yang berkaitan dengan topik yang diberikan. Proses kedua (Group), murid mencari ahli kumpulan sendiri dan berkongsi idea dengannya. Manakala proses ketiga (Share), murid berkongsi secara lisan atau bukan lisan. Proses ketiga ini boleh dalam bentuk cadangan, idea dan hasil kerja.

Dalam kajian ini, Think-Group-Share diaplikasikan di peringkat intervensi yang berbeza iaitu peringkat lisan, peringkat melalui tugasan dan peringkat melalui bermain. Pengkaji membuat keputusan untuk memberi fokus kepada lisan terlebih dahulu iaitu berkongsi idea melalui verbal. Seterusnya, pengkaji menyediakan tugasan yang membolehkan murid berkongsi dan bekerjasama. Akhirnya, pengkaji akan menyediakan aktiviti yang memerlukan kemahiran tertentu dalam menyelesaikan masalah. Ketiga-tiga peringkat ini akan mengalami proses yang sama iaitu "Think" 
(memikir), "Group" (berkumpulan) dan "Share" (berkongsi).
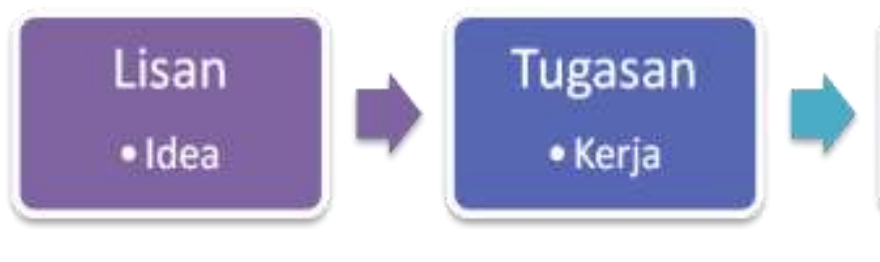

Aktiviti

- Bermain

Rajah 2: Peringkat intervensi berdasarkan proses Think-Group-Share

\section{Menganalisis Data}

Dalam proses menganalisis data, pengkaji menganalisis data kualitatif berbentuk deskriptif. Data yang dianalisis termasuk data pemerhatian, transkrip temu bual dan rekod anekdot. Pengkaji telah merumuskan kekerapan berlaku tingkah laku berkongsi sebelum dan selepas bagi peserta kajian A, B, C dan D. Bagi menjawab persoalan di atas, pengkaji telah menjalankan pemerhatian. Antara instrumen yang digunakan termasuk senarai semak, temu bual dan rekod anekdot.

Jadual 1: Perbandingan prestasi perkembangan sosioemosi sebelum intervensi dan selepas intervensi

\begin{tabular}{cccccccc}
\hline \multicolumn{2}{c}{$\begin{array}{c}\text { Peserta kajian A } \\
\text { Skor }\end{array}$} & \multicolumn{2}{c}{$\begin{array}{c}\text { Peserta kajian B } \\
\text { Skor }\end{array}$} & \multicolumn{2}{c}{$\begin{array}{c}\text { Peserta kajian C } \\
\text { Skor }\end{array}$} & \multicolumn{2}{c}{$\begin{array}{c}\text { Peserta kajian D } \\
\text { Skor }\end{array}$} \\
Sebelum & Selepas & Sebelum & Selepas & Sebelum & Selepas & Sebelum & Selepas \\
\hline 43 & 57 & 43 & 48 & 38 & 37 & 40 & 52 \\
51 & 71 & 54 & 67 & 44 & 62 & 44 & 65 \\
52 & 108 & 48 & 100 & 33 & 67 & 36 & 114 \\
59 & 113 & 59 & 94 & 55 & 62 & 52 & 92 \\
53 & 109 & 33 & 58 & 33 & 69 & 37 & 47 \\
\hline 258 & 458 & 237 & 367 & 203 & 297 & 209 & 370 \\
\hline
\end{tabular}


Jurnal Pendidikan Awal Kanak-Kanak Kebangsaan 2017 Special Issue (48-66)

(ISSN 2289-3032 / eISSN 2550-178X)

https://ejournal.upsi.edu.my/journal/JPAK

Jadual 2: Kekerapan yang menunjukkan tahap perkembangan

\begin{tabular}{rc}
\hline Kekerapan & Tahap \\
\hline $0-100$ & Lemah \\
$101-200$ & Sederhana \\
$201-300$ & Memuaskan \\
$301-400$ & Baik \\
400 ke atas & Cemerlang \\
\hline
\end{tabular}

Jadual 1 ialah jadual perbandingan prestasi perkembangan sosioemosi sebelum intervensi dan selepas intervensi manakala Jadual 2 menunjukkan kekerapan yang menunjukkan tahap perkembangan. Skala yang digunakan berdasarkan Methods Successive Interval (MSI). Metode skala ini diubahsuai dengan menaikkan skala pengukuran ordinal ke skala pengukuran interval supaya pengubahsuaian yang dilaksanakan sesuai diaplikasikan dalam kajian ini.

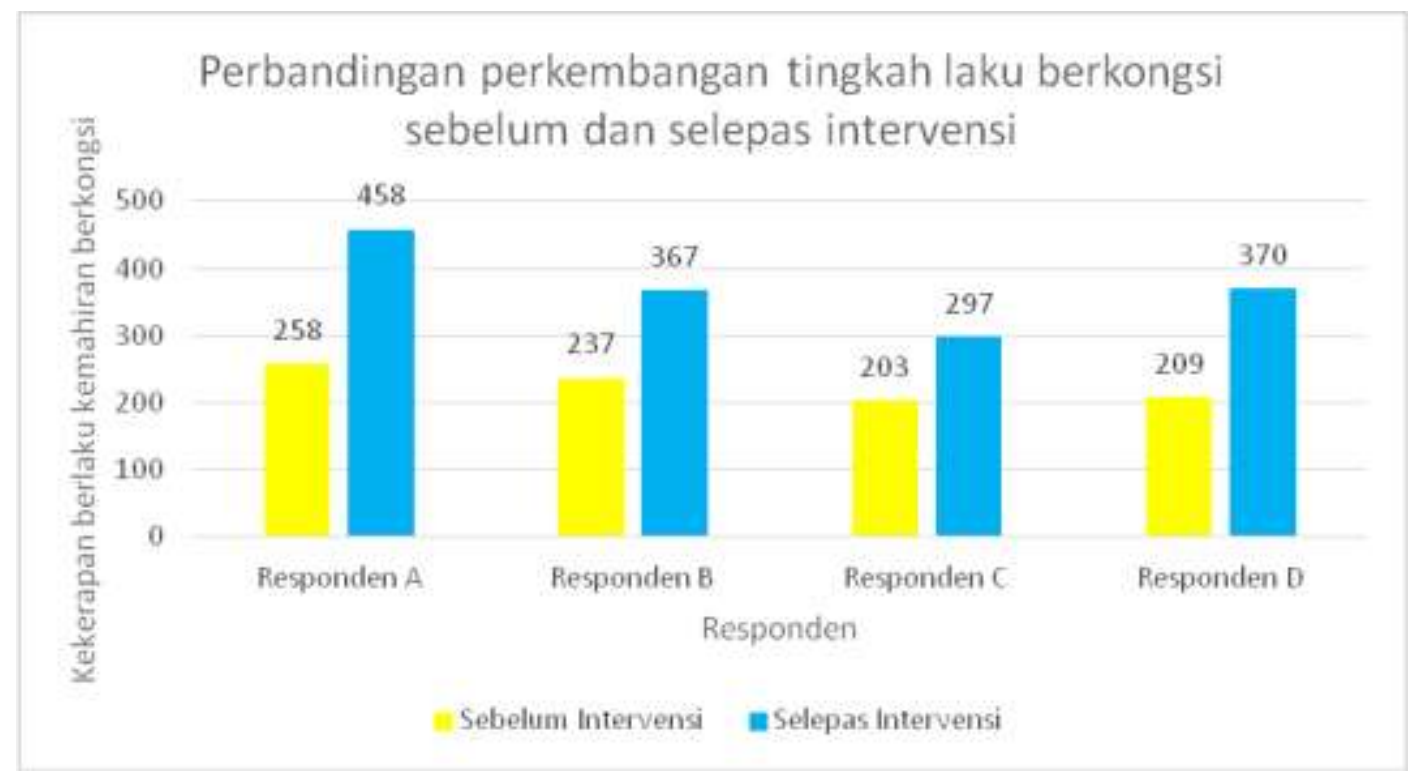

Rajah 1: Graf bar menunjukkan perbandingan kemahiran berkongsi sebelum dan selepas intervensi 
Rajah 1 menunjukkan wujudnya peningkatan tingkah laku berkongsi berlaku selepas intervensi berbanding dengan sebelum intervensi. Sebelum intervensi, tingkah laku berkongsi untuk peserta kajian kurang memuaskan. Tingkah laku tersebut turut mengakibatkan proses pengajaran dan pembelajaran tidak berjalan dengan lancar. Selepas intervensi dijalankan, peserta kajian yang dipilih telah berjaya menunjukkan tingkah laku berkongsi dan nilai kerjasama semasa proses pdp. Contohnya, murid saling memberi pendapat tentang cara menyusun blok yang pelbagai bentuk ke dalam kotak yang dibekalkan semasa mengemas.

\section{Dapatan Kajian}

Dapatan daripada bilangan kekerapan sebelum intervensi dan selepas intervensi membuktikan keberkesanan penggunaan kaedah Think-Group-Share untuk meningkatkan kemahiran berkongsi dalam kalangan murid prasekolah. Nilai murni bekerjasama juga dapat dipupuk apabila peserta kajian menunjukkan kerjasama dalam aktiviti yang disediakan. Selepas menggunakan kaedah Think-Group-Share, prestasi peserta kajian A, telah meningkatkan 2 tahap iaitu dari tahap memuaskan ke tahap cemerlang. Peserta kajian B dan D pula menunjukkan kenaikan satu tahap iaitu dari tahap memuaskan ke tahap baik. Lantas itu, dengan kaedah Think-Group-Share dapat mengatasi masalah keempat-empat peserta kajian yang menunjukkan kemahiran berkongsi yang lebih kerap berlaku berbanding dengan sebelum intervensinya. Didapati bahawa peserta kajian dapat memupuk nilai bekerjasama apabila mereka menunjukkan tingkah laku bermain bersama dalam kumpulan tanpa diberi arahan. Ini menunjukkan bahawa kaedah ini dapat membantu peserta kajian lebih memahami tingkah laku yang sepatutnya diamalkan semasa menjalankan aktiviti kumpulan.

Semasa aktiviti dijalankan, semua peserta kajian berupaya menunjukkan kemahiran berkongsi idea dan peralatan dalam kumpulan. Semua peserta kajian boleh melibatkan diri dalam aktiviti yang disediakan dengan aktif. Mereka saling berbincang untuk mencari penyelesaian masalah. Contohnya, 
Jurnal Pendidikan Awal Kanak-Kanak Kebangsaan 2017 Special Issue (48-66)

(ISSN 2289-3032 / eISSN 2550-178X)

https://ejournal.upsi.edu.my/journal/JPAK

semasa bermain batu berwarna, keempat-empat peserta kajian menunjukkan cara berkongsi yang berbeza. Misalnya berkongsi pendapat terhadap cara menyusun batu berwarna, membantu ahli kumpulan menyusun batu berwarna dan juga memberitahu huruf seterusnya yang perlu disusun. Apabila pengkaji sedang menyediakan alat permainan yang diperlukan dalam proses pengajaran dan pembelajaran, peserta kajian telah mengajak murid yang lain duduk bersama dalam kumpulan walaupun arahan belum diberikan.

\section{Refleksi}

Pengalaman pengajaran pengkaji telah menunjukkan kelemahan murid dalam menguasai kemahiran berkongsi. Kelemahan ini juga telah memberi kesan negatif dalam pengurusan bilik darjah. Oleh itu, pengkaji telah memilih fokus kajian ini dan merancang intervensi yang sesuai sebagai peluang untuk murid membaiki kelemahan tersebut. Menurut Piaget (seperti petikan dalam Michaelene dan Hedda, 2010) menyatakan bahawa kanak-kanak melihat semua adalah keupayaannya kerana pemikiran kanak-kanak pada peringkat pra-operasi adalah bersifat egosentrik. Mereka hanya boleh berfikir berdasarkan pandangan sendiri sahaja dan tidak berupaya melihat pandangan orang lain. Oleh itu, mereka kurang mampu memahami perasaan orang lain kerana mereka menganggap segala perbuatannya adalah betul dan kurang mampu menerima pendapat dan cadangan orang lain. Sepanjang Think-Group-Share diaplikasikan terhadap peserta kajian yang dipilih, pengkaji mendapati bahawa kaedah pengajaran ini adalah berkesan dalam membantu murid menguasai kemahiran berkongsi dan meningkatkan nilai kerjasama. Data yang dianalisis menunjukkan peningkatan yang mendadak sebelum dan selepas intervensi diadakan. Peningkatan kekerapan murid berkongsi dan bekerjasama dalam aktiviti yang dirancang menunjukkan keberkesanan Think-Group-Share dalam membantu murid menguasai kemahiran berkongsi dan bekerjasama. 
Selain itu, pengkaji juga mendapati bahawa kaedah Think-Group-Share ini bukan sahaja dapat membantu murid menguasai kemahiran berkongsi dan bekerjasama tetapi juga membantu murid menyelesaikan sesuatu tugasan dengan lebih berkesan dalam suasana yang lebih menyeronokkan. Sepanjang kaedah ini diaplikasikan, pengkaji menampak muridnya lebih aktif dalam melibatkan diri dalam aktiviti. Kemahiran sosial seperti berbincang bersama untuk mendapatkan cara penyelesaian telah banyak berlaku. Kesan positif ini menunjukkan kaedah Think-Group-Share bukan sahaja membantu mencapai objektif kajian tetapi juga membantu perkembangan dalam pelbagai aspek dan tunjang.

\section{Cadangan Tindakan Susulan}

Pengkaji bercadang menyenaraikan bentuk item khas pada setiap peringkat intervensi iaitu peringkat lisan, peringkat tugasan dan peringkat aktiviti. Ini dapat memberi gambaran awal kepada pengkaji terhadap tingkah laku yang kemungkinan peserta kajian tunjukkan dalam setiap peringkat intervensi. Ini juga dapat memberi kesediaan kepada pengkaji tentang apa dan bagaimana setiap peringkat intervensi harus dijalankan. Aspek yang kedua merupakan cara melaksanakan intervensi. Pengkaji hanya memulakan intervensi dengan set induksi dan langkah-langkah yang seterusnya seperti biasa dalam proses pengajaran dan pembelajaran harian. Pengkaji bercadang mengadakan langkah tambahan sebelum intervensi diadakan supaya tingkah laku murid lebih berfokus. Memandangkan keberkesanan kaedah ini, kajian lanjut boleh digunakan dalam aspek dan tunjang yang lain. Dengan cara ini, harapan pendidikan di Malaysia untuk memperkembangkan potensi individu secara menyeluruh dari segi intelek, rohani, emosi dan jasmani dapat dicapai.

\section{RUJUKAN}

Australian Goverrnment Department of Social Services. (2006-2016). Raising children network (Australia). Diperoleh Ogos 2, 2016 dari http://m.raisingchildren.net.au/ 
Jurnal Pendidikan Awal Kanak-Kanak Kebangsaan 2017 Special Issue (48-66)

(ISSN 2289-3032 / eISSN 2550-178X)

https://ejournal.upsi.edu.my/journal/JPAK

Bagnato, S. J. (2007). Authentic assessment for early childhood intervention best practices. New York: The Guilford Press.

Bahagian Pembangunan Kurikulum. (2010). Dokumen standard kurikulum prasekolah. Putrajaya: Kementerian Pelajaran Malaysia.

Boyd, J. et al. (2005). dalam NIEER. Promoting children's social and emotional development through preschool education. Diperoleh Ogos 5, 2016 dari http://nieer.org/resources/policyreports/report7.pdf

Brogle, B., Jiron, A., dan Giacomini, J. (2013). How to help your child learn to share. Diperolehi September 24, 2016 dari

http://challengingbehavior.fmhi.usf.edu/do/resources/documents/bkpk_share.pd $\underline{f}$

Hirsh-Pasek, K., et al. (2009). A mandate for playful learning in preschool: presenting the evidence. New York: Oxford University Press.

Kementerian Pelajaran Malaysia. (2010). Dokumen standard kurikulum prasekolah. Putrajaya: Kementerian Pelajaran Malaysia

Lyons, S. (2016). Benefits of cooperative games. Diperoleh Julai 27, 2016 dari http://cooperativegames.com/benefits-of-cooperative-games/

Michaelene, M. O. dan Hedda, M. (2010). Young children: Helping children play and learn together. Diperoleh Julai 29, 2016 dari https://www.naeyc.org/files/yc/file/201001/OstroskyWeb0110.pdf

Oxford Dictionaries. (2016). Oxford University Press. Diperoleh Ogos 2, 2016 dari http://www.oxforddictionaries.com/ms/

Pellegrini, A. D. (2009). The role of play in human development. New York: Oxford University Press.

Provenzo, E. F. (2009). Friedrich Froebel's gifts: Connecting the spiritual and aesthetic to the Real World of Play and Learning. American Journal of Play. $85-9$.

Ramani, G. B., dan Brownell, C. A. (2013). Preschoolers' cooperative problem solving: Integrating play and problem solving. Journal of Early Childhood Research. 12(1) 92-108

Short-Meyerson KJ (2010) Preschoolers' establishment of mutual knowledge during 
Think-Group-Share Meningkatkan Kemahiran Berkongsi

Dalam Kalangan Murid Prasekolah

scripted interactions. 30: 219-236.

Wexner Medical Center. (2012). Helpful Hints for Sharing Among Children.

Diperoleh Ogos 5, 2016 dari

https://patienteducation.osumc.edu/Documents/sharing.pdf

Yunus Abidin. (2010). Strategi membaca teori dan pembelajarannya. Bandung: Risqi Press. 


\section{SENARAI SEMAK PERKEMBANGAN SOSIOEMOSI}

KANAK-KANAK

NAMA :
UMUR :
TARIKH :

JANTINA :

BANGSA :

MASA :

\begin{tabular}{|c|l|c|c|c|}
\hline Bil & \multicolumn{1}{|c|}{ Item-item } & Ya & Tidak & Catatan \\
\hline $\mathbf{1}$ & Penglibatan diri dalam aktiviti main & & & \\
\hline $\mathbf{2}$ & $\begin{array}{l}\text { Meminta keizinan dalam menggunakan atau meminjam } \\
\text { barang orang lain }\end{array}$ & & & \\
\hline $\mathbf{3}$ & Pemulangan barang selepas meminjam & & & \\
\hline $\mathbf{4}$ & $\begin{array}{l}\text { Pengucapan terima kasih kepada rakan semasa aktiviti } \\
\text { diadakan }\end{array}$ & & & \\
\hline $\mathbf{5}$ & $\begin{array}{l}\text { Berkongsi barang atau peralatan permainan dalam } \\
\text { aktiviti }\end{array}$ & & & \\
\hline $\mathbf{6}$ & Komunikasi dengan rakan semasa aktiviti & & & \\
\hline $\mathbf{7}$ & Bertolak ansur semasa menjalankan aktiviti & & \\
\hline $\mathbf{8}$ & Bekerjasama semasa menjalankan aktiviti & $\begin{array}{l}\text { Penyelesaian konflik antara rakan melalui kaedah seperti } \\
\text { perbincangan / perundingan (negotiation) }\end{array}$ & & \\
\hline $\mathbf{1 0}$ & $\begin{array}{l}\text { Bersikap sensitif / menyedari terhadap keperluan orang } \\
\text { lain }\end{array}$ & & & \\
\hline
\end{tabular}

Diadaptasi dan diubahsuai dari Teaching \& Learning Company, The McGraw-Hill Companies, First Look and The Early Childhood Direction Center dan Kurikulum Standard Prasekolah Kebangsaan. 